The $5^{\text {th }}$ International Conference on Family Business and Entrepreneurship

\title{
INTERNAL CONTROL MECHANISM IN MITIGATING FRAUD RISK CASES AT ACCOUNT REPRESENTATIVES AT KPP PRATAMA X
}

\author{
Fitri Zulvina ${ }^{1}$ \\ ${ }^{l}$ Faculty of Economy and Business, Universitas Indonesia, fitrizulvina@ gmail.com
}

\begin{abstract}
:
The practice of fraud in the government sector has become a topic of discussion in the Indonesian media. The Directorate General of Taxes as one of the institutions that focuses on the anti-corruption movement has also become a news highlight with the arrest of one of the directors related to fraud. This study aims to identify the internal control mechanism at the KPP Pratama $X$ in mitigating fraud risk. The process of identifying internal control mechanisms is carried out using the concept of Three Lines of Defense. The study was conducted at the position of Account Representative because the position has the potential for a greater risk of fraud compared to other positions at the KPP Pratama $X$. The research method used is a qualitative descriptive method, which uses the data obtained from reports at the KPP Pratama X and interviews which are then analyzed using qualitative methods. From the field data obtained, it is known that the KPP Pratama $X$ is still not optimal in carrying out internal control mechanisms in mitigating fraud risk. The results of the study are expected to provide input in the development of internal control mechanisms so that fraud risk can be mitigated properly.
\end{abstract}

Keywords: Fraud, Internal Control, COSO Internal Control, Three Lines of Defence, Primary Tax Office.

\section{Introduction}

The Directorate General of Taxes, which is part of the Ministry of Finance, plays an important role in the running of the government, namely in collecting state revenues from taxes. In the 2019 APBN, it is known that the total target of Tax Revenue is Rp. 1,786.4 trillion of the total revenue target of Rp. 2,165.1 trillion. In implementing, of course, the Directorate General of Taxes has risks that might hinder the main objective of collecting state revenues. The biggest risk for the Directorate General of Taxes is the risk of not meeting the tax revenue target. The risk of not achieving the tax revenue target can come from internal or external to the Directorate General of Taxes. External causes can be in the form of policies and economic activities, while internal causes can come from organizational performance that has not been optimal in terms of objectives. To support the improvement of organizational performance, the Minister of Finance in the Decree of the Minister of Finance (Kementerian Keuangan, 2011a) concerning the Values of the Ministry of Finance, stipulates that Integrity, Professionalism, Synergy, Service, and Perfection become the basis and foundation for the Ministry of Finance institutions, leaders and all employees in serving, working and working.

Based on media reports it is known that there were several acts of corruption involving employees and/or officials of the Directorate General of Taxes, such as the corruption case of Gayus Tambunan (in 2010), the extortion case of Ramli Aruan (in 2018), and the most recent the bribery case of Sulimin Ratmin (in 2018). From several cases of stinging operations, it is known that the types of fraud committed by individuals are bribery and extortion (economic extortion). Based on the results of a survey conducted by 
the Association of Certified Fraud Examiners (ACFE) in the Indonesia Fraud Survey (2019), it is known that the most common type of fraud committed by agencies in Indonesia is corruption, with the government being the most disadvantaged. The following is a graph of fraud in Indonesia.

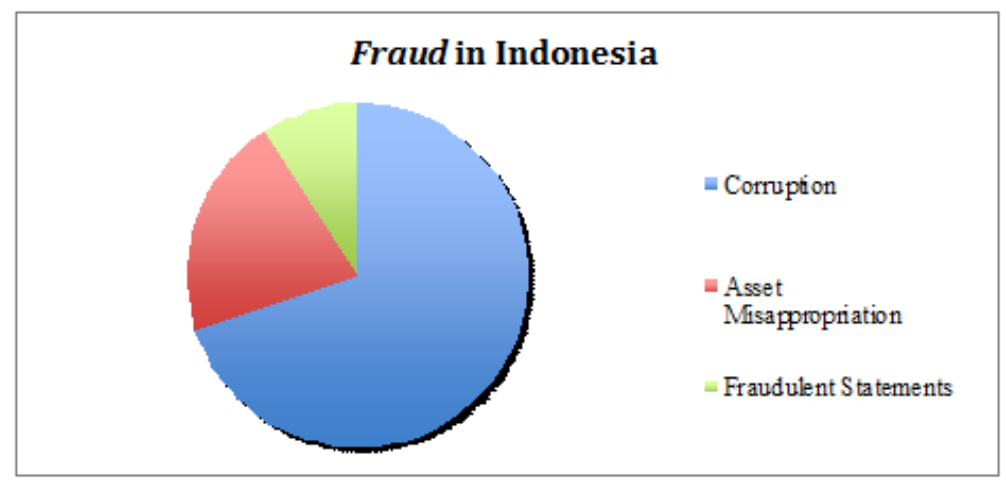

Figure 1. Fraud in Indonesia

(Source: ACFE, 2019)

Based on the background described above, it can be seen that the problems in this study are How is internal control mechanism in mitigating fraud at the KPP Pratama X? and How to improve internal control in mitigating fraud at the KPP Pratama X?

The purpose of the research is to Provide an overview of internal control mechanism in mitigating fraud at the KPP Pratama X; and Provide recommendations in increasing the effectiveness of internal control in mitigating fraud at the KPP Pratama X.

\section{Literature Review}

\section{Fraud}

The background of the emergence of fraud can be explained by the agency theory of Jensen and Meckling (1976). Agency theory from Jensen and Meckling (1976) explains the contractual relationship between principal and agent. Jensen and Meckling (1976) stated that every cooperation contract entered into by a person or organization could potentially create a conflict of interest. This conflict of interest arises because of human nature which is self-interested. Humans will always try to maximize their prosperity even if they have to sacrifice the prosperity of others. Scoot (2006) states that in the management control system there is a principal and agent relationship, where the principal in this case is the leader. The leader appoints someone as an agent to carry out decentralization. According to Scoot (2006), both the principal and the agent are assumed to be rational economic people who always try to maximize their utility even though they can sacrifice the prosperity of others. Thus, a condition called fraud is created.

Literally fraud is defined as cheating. Albrecht et al. (2012: 6) in the book Fraud Examination, the notion of fraud includes various meanings where human ingenuity can be a tool that one chooses to take advantage of others by misrepresentation. According to Vona (2008), fraud is an act, illegal or showing wrongdoing, committed by an internal or external party intentionally or hidden, which causes the loss of company assets, company reputation, company value, or other unauthorized benefits, whether received or not received personally or by others. From these several definitions of fraud, it can be said that fraud is a fraudulent act or attitude committed by someone to gain personal gain that can harm the organization. 


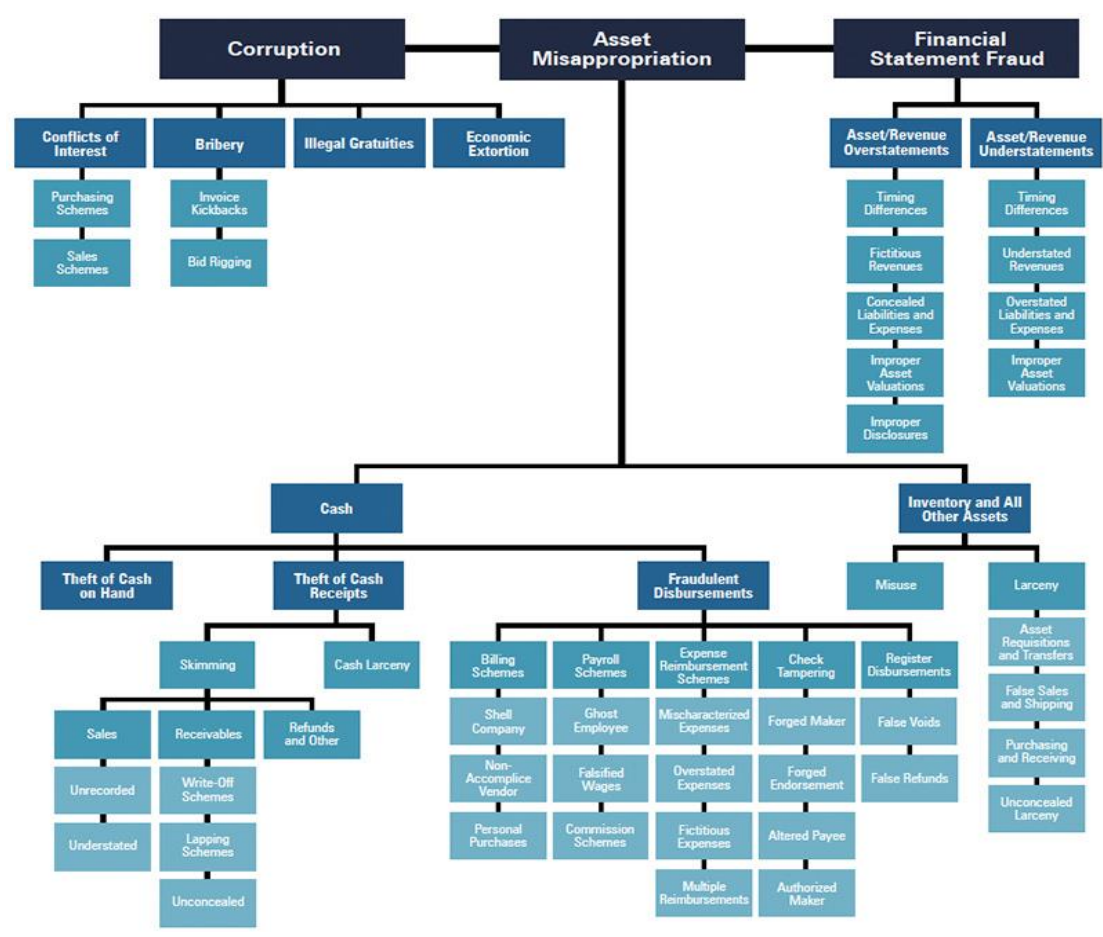

Figure 2. Fraud Tree

(Source: ACFE, 2019)

The Association of Certified Fraud Examiners (ACFE) (2019) classifies internal fraud actions into 3 types, namely:

a) misappropriation of assets, is an act of misappropriation or theft of organizational assets for personal purposes. This fraud has a high risk of occurrence but has a small impact;

b) fraudulent statements, which are intentional behavior or forms of carelessness, either through actions or by deletion, which causes the information contained in the report to mislead users;

c) Corruption is an act of fraud in the exercise of authority. This type of fraud has a small risk of occurrence but causes large losses.

Three Lines of Defense

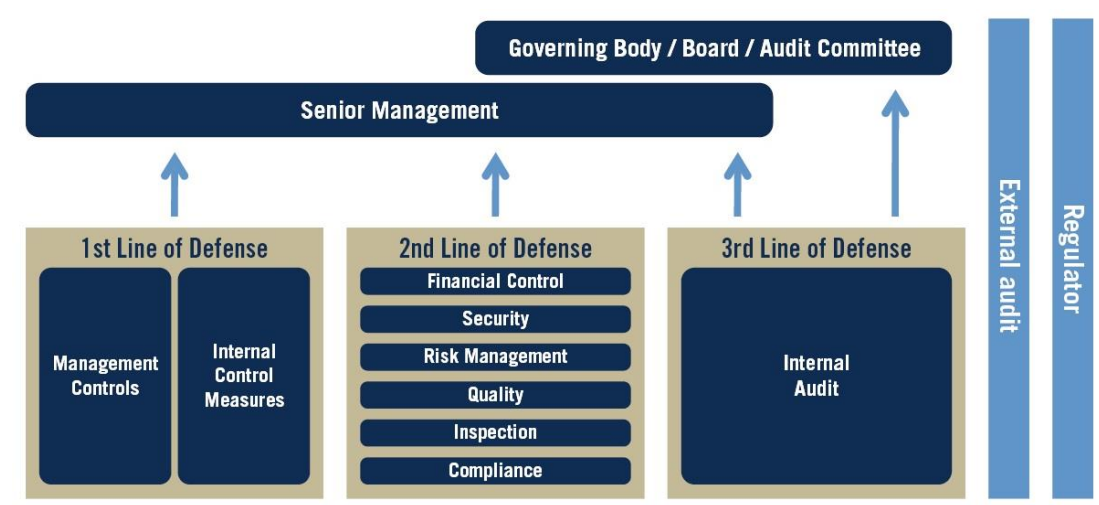

Figure 3. Three Lines of Defense

(Source: ECIIA/FERMA Guidance, 2013)

21

C 2021 . The $5^{\text {th }}$ International Conference on Family Business and Entrepreneurship 
Three lines defense is a mechanism that can improve the performance of internal control in risk management (IIA, 2013). The Three Lines of Defense distinguishes between the existing business functions in the organizational unit into owning risks/risk owners, functions that manage risks (managing risks), and functions that oversee risks (overseeing risks) with functions that provide independent assurance. All of these functions play an important role in risk management in government organizations. The Three Lines of Defense is divided into three levels, namely:

First Line Defense (Risk Owner)

First Line Defense is carried out by units or components or business functions that carry out daily operational activities of the organization, especially those who deal directly with external parties or those who run the organization's main business processes. In the implementation of internal control, the risk owner is responsible for:

a. Identify, assess and mitigate risks. The risk owner plays a role in ensuring a conducive control environment in the business unit;

b. Implement corrective action. The risk owner plays a role in implementing the risk management policies that have been determined when carrying out their duties and functions, especially in achieving organizational growth. The risk owner is expected to be fully aware of the risk factors in the decisions and actions taken; and

c. Implement and evaluate controls. The risk owner plays a role in demonstrating the existence of effective internal controls in the business unit, as well as monitoring and transparency of the effectiveness of these internal controls. As part of an organization that carries out operational functions directly, the risk owner can assess control activities that are no longer relevant in mitigating the risks contained in the organization, so that it becomes an evaluation material in the control mechanism.

\section{Second Line Defense}

Second Line Defense is carried out by risk management and compliance functions, especially risk management and compliance functions that have been structured such as risk management and compliance units. In this case, Second Line Defense is expected to:

a. Responsible for developing and monitoring the implementation of the company's overall risk management.

b. Supervise how business functions are carried out within the corridor of risk management policies and standard operating procedures set by the company.

c. Monitor and report overall company risks to the organ that has the highest accountability in the company.

The risk management and compliance unit analyzes the risks owned by the organizational unit then determines the level of acceptable risk and makes risk management mechanisms that can be carried out in achieving the acceptable risk.

\section{Third Line Defense}

The last level in the Three Lines of Defense mechanism is Third Line Defense, namely the establishment of a unit that provides assurance that the implementation of internal control in risk management has been carried out effectively. This assurance activity is carried out by a unit called internal audit. Third Line Defense is implemented by internal auditors. The role of internal auditors is much more intense in the Three Lines of Defense model because it is an internal part of the company that is independent of other functions. In this case, the internal audit function is expected to: review and evaluate the overall design and implementation of risk management; and ensure that First Line and Second Line Defense run as expected. 


\section{Research Method}

The unit of analysis in this study is the KPP Pratama X, which is one of the work units of public sector organizations in Indonesia. The reason for choosing the Primary Tax Office is because it has the same organizational structure as several Tax Offices related to fraud cases in Indonesia, these tax offices are generally in the form of the Primary Tax Office. In addition, the organizational structure of the Primary Tax Service Office is the organizational structure of the work unit with the highest number at the Directorate General of Taxes.

The KPP Pratama X consists of 99 employees, with details of 11 Structural positions, 30 Account Representative positions, 12 Tax Auditor Functional positions, and 45 executives. Of the 30 employees with the position of Account Representative, there are 5 employees who carry out the Strategic Account Representative in Supervision Section I and 25 employees who carry out the regional supervisory function in the Supervision Section I, II, III, IV, V and VI. The data used in this study is a combination of primary data and secondary data. Primary data is data obtained directly by researchers from the unit of analysis. Meanwhile, secondary data is data obtained from other parties, such as reports and data from the Directorate General of Taxes database. Primary data were obtained through interviews and field observations conducted on Account Representatives at the KPP Pratama X. The interviews were conducted using semi-structured to depth session techniques to be able to further explore the information contained in the research focus. While secondary data is obtained by requesting the required data and information to the relevant agencies. This study uses qualitative data analysis methods. Qualitative research is research with the aim of obtaining information and in-depth understanding of the data in the field and drawing conclusions to solve problems. The data and information that have been obtained will be triangulated with reports and observations in order to produce more valid information. These results are then juxtaposed with the theory and previous research to get a better problem solving.

\section{Results and Discussion}

The KPP Pratama $\mathrm{X}$ is a vertical unit at the Directorate General of Taxes that performs the function of counseling, servicing, and supervising Taxpayers in certain locations. In accordance with the Regulation of the Minister of Finance number 184/PMK.01/2020 concerning the Organization and Work Procedure of the Directorate General of Taxes, the KPP Pratama X has an organizational structure consisting of the Head of Office, Service Section, Data Quality Assurance Section, Tax Audit and Collection Section, Supervision Section I, Supervision and Consultation Section II, Supervision and Consultation Section III, Supervision and Consultation Section IV, Supervision and Consultation Section V, Supervision and Consultation Section VI, and General Subdivision and Internal Compliance. At the KPP Pratama X there is also a Tax Auditor and Tax Counselor which are directly under the head of the work unit. Overall, the KPP Pratama $\mathrm{X}$ has an organizational structure that is in accordance with applicable regulations.

In carrying out internal control activities, the KPP Pratama X follows the regulations and policies issued from the government, namely, Government Regulation number 60 of 2008 concerning Government Internal Control System (SPIP), Minister of Finance Decree number 130/KMK.09/2013 concerning The Ministry of Finance's Internal Supervision Policy and the Director General of Taxes Regulation number PER-42 /PJ/2013 concerning the Implementation of the Duties of the Internal Compliance Unit in Vertical Agencies and Technical Implementation Units within the Directorate General of Taxes.

In 2016 the Ministry of Finance issued Regulation of the Minister of Finance number 237/PMK.09/2016 concerning Governance of Internal Control within the Ministry of Finance. A year later the Ministry of Finance again refined the regulations regarding the implementation of internal control within the Ministry of Finance by issuing the Minister of Finance Decree number 940/KMK.09/2017 concerning the Framework for the Implementation of Internal Control and Guidelines for Monitoring Internal Control within the Ministry of Finance. However, these regulations have not been harmonized into the regulations of the Directorate General of Taxes so that the latest regulation related to the implementation of internal 
control at the Directorate General of Taxes is the Regulation of the Director General of Taxes number PER42/PJ/2013 concerning the Implementation of the Duties of the Internal Compliance Unit in Vertical Agencies and Technical Implementation Units. within the Directorate General of Taxes.

In the Regulation of the Director General of Taxes number PER-42/PJ/2013, the function of the Internal Compliance Unit at the Tax Service Office is carried out by the Internal Audit and Compliance Section, but with the enactment of the Minister of Finance Regulation number 206.2/PMK.01/2014 concerning Organization and Work Procedures of Agencies Vertical of the Directorate General of Taxes, the function of the Internal Compliance Unit is carried out by the General Subdivision and Internal Compliance.

The Three Lines of Defense mechanism in mitigating the risk of fraud at the KPP Pratama X First Line Defense - Risk Owner Unit - Account Representative

The KPP Pratama X has six sections that carry out the supervisory function of Taxpayers, namely the Supervision Section I, II, III, IV, V, and VI. Each section has five Account Representatives headed by one Section Head. The distribution of taxpayers at the KPP Pratama X is carried out based on the work area, beside Strategic Account Representative.

Taxpayer supervision is carried out by the Account Representative determined based on the work area and certain characteristics of the Taxpayer. In addition, there are Account Representatives who carry out supervision of Taxpayers determining revenue, namely a number of Taxpayers who contribute the largest revenue to the KPP Pratama X.

Table 1. Comparison of the Number of Account Representatives and Taxpayers of KPP Pratama X

\begin{tabular}{lr}
\hline Account Representative & \multicolumn{1}{c}{ Num } \\
\hline Strategic AR (each AR for 100 Taxpayer) & 5 \\
Regional AR & 25 \\
Total Taxpayer & 230.000 \\
Regional AR : Taxpayer & $1: 9.000$ \\
\hline
\end{tabular}

In addition to analyzing and supervising taxpayer compliance in terms of potential exploration, the Account Representative also carries out a series of non-potential exploration activities, namely providing counseling and visits related to Requests for Explanation of Data and/or Information (SP2DK). Visits are carried out to update taxpayer data in the tax system, such as Classification of Business Fields and correspondence addresses.

Table 2. Account Representative Performance of KPP Pratama X for the January-July 2021 Period

\begin{tabular}{lr}
\hline Penggalian Potensi & \multicolumn{1}{c}{ Num } \\
\hline SP2DK & 4.350 \\
LHP2DK & 255 \\
STP & 3.624 \\
Riksus & 10 \\
Audit P3 & 3 \\
Non Extra Effort & \\
Consultation & 86 \\
Correspondence & 4 \\
Visit & 130 \\
\hline
\end{tabular}

Based on the Account Representative performance data in the table 1 and 2 showed that KPP Pratama X there are still SP2DKs that have not been finalized into Reports on the Results of Requests for Explanation 
of Data and/or Information (LHP2DK). Follow-up from LHP2DK can be in the form of proposals for special inspections, further supervision, or status completed. The condition that SP2DK has not changed to LHP2DK can be due to the large number of SP2DKs that have not been followed up on a system basis and because Taxpayers have not provided explanations and information regarding the data and information contained in the SP2DK. The processing of SP2DK into LHP2DK on the Approweb system is one of the control mechanisms, namely an adequate documentation process, which is supervised by the direct supervisor. This activity requires evidence in the form of physical documentation which is then scanned into an electronic document and uploaded to the approweb application. With the large number of SP2DK and various processes that must be carried out to follow up, the time required to produce LHP2DK is relatively long. If each Account Representative is responsible for completing 1,506 SP2DK in one year (6,025 SP2DK divided by 24 Account Representatives), then the workload to complete all SP2DK is too big. This is the reason for the Account Representative not implementing the SOP as a whole.

Table 3 below is a list of SOPs that are still valid for the supervision business process carried out by the Account Representative in the supervision section at the KPP Pratama X. However, the SOP has not been able to reflect the overall work of the Account Representative in the KPP Pratama X because the total number of activities carried out by the Account Representative is quite large.

Table 3. Standard Operating Procedures of Account Representative in Primary Tax Office

\begin{tabular}{|c|c|c|}
\hline No & SOP Code & SOP title \\
\hline 1 & KPP70-0164 & $\begin{array}{l}\text { Follow-up to Taxpayers who Do not Respond to Requests for Explanation of Data } \\
\text { and/or Information }\end{array}$ \\
\hline 2 & KPP70-0165 & Request for Explanation of Data and/or Information to Taxpayers \\
\hline 3 & KPP70-0166 & Cancellation of SKB PPN BKP Strategically by Position \\
\hline 4 & KPP70-0063 & $\begin{array}{l}\text { Procedures for Issuing Tax Collection Letters (STP) in the Supervision and } \\
\text { Consultation Section }\end{array}$ \\
\hline
\end{tabular}

\section{Second Line Defense - Internal Compliance Unit}

The position of the Internal Compliance Unit which is in a structural unit that is not directly under the head of the work unit sometimes causes a conflict of interest from the implementer of the Internal Compliance Unit. On the one hand, the Internal Compliance Unit functions to enforce internal controls, on the other hand, the Internal Compliance Unit does not have enough power because it has the same position as other units.

Implementers assigned to the Internal Compliance Unit are employees with special qualifications that have been determined by the Directorate of KITSDA. One of the requirements is to have served as a Civil Servant for two years.

\section{Improving internal control in mitigating fraud at the KPP Pratama X}

Existence of Internal Audit (Third Line of Defence)

Based on the analysis of the internal control mechanism in mitigating fraud at the KPP Pratama X, it is known that the implementation of internal control at the KPP Pratama X has not been effective because it has not been implemented in its entirety and the three lines of defense have not been implemented perfectly because it has not been implemented. the existence of a third line of defense, namely internal audit.

\section{Assignment of tasks and functions}

The duties and functions of the account representative at the KPP Pratama X do not work properly because the workload of each individual is too large. If divided equally, each account representative has the responsibility to manage the performance of 9,000 Taxpayers through business process supervision. As a 
consequence, account representatives do not carry out activity documentation as required in the SOP. For this reason, it is expected that the KPP Pratama X can perform a better workload analysis on account representatives in order to achieve organizational goals and the internal control mechanism is well underway.

\section{Comprehensive SOP implementation}

Based on the operational activities carried out by account representatives at the KPP Pratama X, it is known that there are still several SOPs that are not implemented properly, namely in terms of administrative activities that have been carried out. Many supervisory activities carried out by account representatives have not been administratively documented so that the monitoring activities of the implemented controls cannot be implemented properly. From the example above, it can be concluded that the account representative do not carry out SOPs in terms of administrative documentation. For this reason, the KPP Pratama X needs to confirm the implementation of SOPs in accordance with applicable regulations. This affirmation can be done by strengthening the position of the internal compliance unit with the authority to monitor the administrative implementation for account representatives in the form of inspections and periodic monitoring.

\section{Conclusion and Implications}

\section{Conclusion}

After carrying out all stages of the research, the conclusions that can be conveyed from this research are as follows:

1. The implementation of the internal control mechanism through the Three Lines of Defense concept has not yet been implemented properly because in fact the KPP Pratama X does not yet have an internal audit function that provides assurance on the implementation of the organization's internal control;

2. Recommendations that can be given to the condition of the KPP Pratama $X$ are in terms of improving the existing internal control mechanisms and developing internal control mechanisms by creating an internal audit function. Improvements to the existing internal control mechanisms are carried out by implementing improvements to the assigning tasks and functions, and implementing comprehensive SOPs.

\section{Implication}

The Directorate General of Taxes has and implemented the components in fraud risk management. In order for the policy to run more effectively, the Directorate General of Taxes can formulate clearly and in detail the components and unite them in a comprehensive documentation, so that the components are in a unified system. Furthermore, it is necessary to update the existing regulations related to internal control, namely:

1. Completing the three lines of defense with the presence of an internal audit at the Directorate General of Taxes;

2. Making improvements to SOPs by creating new SOPs in accordance with the duties and functions of the account representative and audit functional positions and revising SOPs that are not in accordance with conditions in the field;

3. Modify the internal compliance unit into an independent unit, even if it is possible to make the position in the internal compliance unit a functional position to maximize its authority; and

4. Completing the inspection process by providing an inspection quality control mechanism that provides assurance that the inspection has been carried out in accordance with applicable regulations.

Suggestions that can be given to the KPP Pratama $X$ are:

1. Maximize the function of the internal compliance unit by participating in monitoring supervision and inspection activities;

2. Internal rotation of Account Representatives who have been in the work unit for more than three years but have not experienced regional mutations; and

3. Improve compliance with the implementation of activities in accordance with existing SOPs. 
Another thing that needs to be considered is the commitment and consistency of the leadership in implementing every fraud risk management activity, not just aborting obligations.

\section{References}

Association of Certified Fraud Examiners Indonesia. (2016). Survai Fraud Indonesia.

Association of Certified Fraud Examiners (2013). Fraud Tree. Association of Certified Fraud Examiners, Inc. http://www.acfe.com/fraud-tree.aspx.

Albrecht et al. (2012). Fraud Examination. Fourth Edition, South Western, a part of Cengage Learning, USA.

Azis, Mohamad AzizalAbd., Hilmi Ab. Rahman, Md. Mahmudul Alam, dan Jamaliah Said. (2015, April). Enhancement of the Accountability of Public Sectors through Integrity System, Internal Control System and Leadership Practices: A Review Study. Paper presented at $7^{\text {th }}$ International Conference on Financial Criminology 2015, Oxford,United Kingdom.

Boynton et al. (2003). Modern Auditing. $7^{\text {th }}$ Edition. USA. Richard D. Irwin Inc.

Chartered Global Management Accountant. (2012). CGMA Report: Fraud Risk Management A guide to good practice. Chartered Global Management Accountant, Inc.

https://www.cgma.org/content/dam/cgma/resources/reports/downloadabledocuments/fraudriskmanageme nt.pdf

Committee of Sponsoring Organizations of the Treadway Commission. (1992). Internal Control-Integrated Framework.

Committee of Sponsoring Organizations of the Treadway Commission. (2013). Fraud Risk Management Guide Executive Summary.

Cressey, D.R. (1953). Other People's Money: A Study of the Social Psychology of Embezzlement. New York: Free Press.

Direktorat Jenderal Pajak. (2018). Keputusan Direktur Jenderal Pajak nomor KEP-193/PJ/2018 tentang Perubahan atas Keputusan Direktur Jenderal Pajak nomor KEP-37/PJ/2017 tentang Petunjuk Pelaksanaan Manajemen Risiko di Lingkungan Direktorat Jenderal Pajak.

Debreceny, Roger S., Glen L. Gray. (2010). Data mining journal entries for fraud detection: An exploratory study. International Journal of Accounting Information Systems, 11(3), pp. 157-181

Dente B. (2014). Understanding Policy Decisions. Springer

Fischer, F., G.J. Miller, M.S. Sidney. (2007). Handbook of Public Policy Analysis: Theory, Politics, and Methods. Taylor \& Francis Group, LLC, New York: CRC Press.

Free, C., Murphy, P.R. (2015). The ties that bind: the decision to co-offend in fraud. Contemporary Accounting Research, 32 (1), pp. 18-54

Hubbard, D. W., (2009). The Failure of Risk Management: Whay its Broken and How to Fix it. Hoboken. New Jersey: John Wiley\& Sons, Inc.

Ikatan Akuntan Indonesia. (2012). Standar Akuntansi Keuangan. Jakarta: IAI

Jensen dan Meckling. (1976). Agency cost of free cash flow, Corporate Finance, and takeovers. American Economic Review, Vol. 76, 323-329

Kementerian Keuangan. (2007). Peraturan Menteri Keuangan Nomor 1/PMK.3/2007 tentang Kode Etik Pegawai Direktorat Jenderal Pajak.

Kementerian Keuangan. (2011a). Keputusan Menteri Keuangan Nomor 312/KMK.01/2011 tentang Nilainilai Kementerian Keuangan.

Kementerian Keuangan. (2011b). Keputusan Menteri Keuangan Nomor 149/KMK.09/2011 tentang Tata Cara Pengelolaan dan Tindak Lanjut Pelaporan Pelanggaran (Whistleblowing) serta Tata Cara Pelaporan dan Publikasi Pelaksanaan Pengelolaan Pelaporan Pelanggaran (Whistleblowing) di Lingkungan Kementerian Keuangan.

Kementerian Keuangan. (2016a). Keputusan Menteri Keuangan Nomor 845/KMK.01/2016 tentang Petunjuk Pelaksanaan Manajemen Risiko di Lingkungan Kementerian Keuangan.

Kementerian Keuangan. (2016b). Peraturan Menteri Keuangan Nomor 171/PMK.01/2016 tentang Manajemen Risiko di Lingkungan Kementerian Keuangan.

Kementerian Keuangan. (2018). Peraturan Menteri Keuangan Nomor 97/PMK/2018 tentang Petunjuk Pelaksanaan Pemeriksaan Pelanggaran Disiplin dan Penjatuhan Hukuman Disiplin Pegawai Negeri Sipil di Lingkungan Kementerian Keuangan.

Kranacher, M. J., Riley, R., \& Wells, J. T. (2010). Forensic accounting and fraud examination. John Wiley \& Sons. 
Kusumaningtias, Rohmawati, Unti Ludigdo, Irianto Gugus, dan Aji Dedi Mulawarman. (2015, Desember). Rethinking of Corporate Governance. Paper presented at $3^{\text {rd }}$ GlobalConference on Business and Social Science-2015, Kuala Lumpur, Malaysia. Desember, 2015. ScienceDirect database.

KPMG Forensic. (2014). Fraud risk management: Developing a strategy for prevention, detection, and response. China: Author.

Lin, Chi-Chen., An-An Chiu., Shaio Yan Huang., David C.Yend. (2015). Detecting the financial statement fraud: The analysis of the differences between data mining techniques and experts' judgments. Knowledge-Based Systems, Volume 89, pp 459-470

Matei, Ani., \& Ciprian Drumasu. (2015). Corporate Governance and Public Sector Entities. Paper presented at $4^{\text {th }}$ World Conference on Business, Economics and Management.

Miles, Mathew B., Michael Huberman, Johnny Saldana. (2014). Qualitative Data Analysis: a Methods Sourcebook. SAGE Publication, Inc.

Moeller, Robert R. (2005). Brink's Modern Internal Auditing. John Wiley \& Sons, Inc, Hoboken, New Jersey.

Ngai, E.W.T., Y. Hu, Y.H. Wong, Y. Chen, X. Sun. (2011). The application of data mining techniques in financial fraud detection: a classification framework and an academic review of literature. Decision Support Systems, 50 (3), pp. 559-569

Otoritas Jasa Keuangan. (2016). Peraturan Otoritas Jasa Keuangan Nomor 18/POJK.03/2016 tentang Penerapan Manajemen Risiko bagi Bank Umum.

Pemerintah Republik Indonesia. (2010). Peraturan Pemerintah nomor 53 Tahun 2010 tentang Disiplin Pegawai Negeri Sipil.

PriceWaterhouseCoopers. (2011). Fighting Fraud in The Public Sector. Australia: Author.

Root, Steven J.. (1998). Beyond COSO Internal Control to Enhance Corporate Governance. John Wiley dan Sons. INC.

Sawyer, Lawrence B., Mortimer A. Dittenhoter \& James H. Scheiner. (2005). Sawyer's Internal Auditing: The Practice of Madern Internal Auditing., $5^{\text {th }}$ Edition., Altamonte Springs, Florida: The Institute of Internal Auditors, Inc.

Scott, William R. (2006). Financial Accounting Theory. International Edition. New Jersey: Prentice Hall. Sarbanes-Oxley Act. (2002). An Act., $107^{\text {th }}$ Congress USA.

The IIA : Standards for the Professional Practice of Internal Auditing and related IIA publication.

Tuanakota, Theodorus M.. (2010). Akuntansi Forensik dan Audit Investigatif. Edisi 2. Jakarta: Penerbit Salemba Empat.

Vona, Leonard. (2008). Fraud Risk Assessment; Building a Fraud Audit Program. New Jersey; John Wiley \& Sons, Inc.

Vona, Leonard. (2013). Fraud Risk; Building a Fraud Audit Program. New Jersey; John Wiley \& Sons, Inc.

Vousinas, Georgios. (2019). Advancing theory of fraud: The SCORE Model, Journal of Financial Crime, Vol. 26 Issue: 1.

Wolfe, D. T. \& Hermanson, D. R. (2004). The Fraud Diamond: Considering the four Elements of Fraud. The CPA Journal, pp.1-5.

CNN Indonesia. (2018). Rentetan Kasus Korupsi yang Menjerat Pegawai Pajak. www.cnnindonesia.com. Diakses pada 18 Mei 2018.

Yulistyowati, Efi dkk. (2016). Penerapan Konsep Trias Politica dalam Sistem Pemerintahan Republik Indonesia: Studi Komparatif atas Undang-undang Dasar Tahun 1945 Sebelum dan Sesudah Amandemen. Jurnal Dinamika Sosial dan Budaya Volume 18 No.2: 328-338. 